\title{
Detection of gill-associated virus (GAV) by in situ hybridization during acute and chronic infections of Penaeus monodon and P. esculentus
}

\author{
Kirsten M. Spann ${ }^{1,2}$, Russell J. McCulloch ${ }^{1}$, Jeff A. Cowley, Iain J. East ${ }^{1,3}$, \\ Peter J. Walker ${ }^{1, *}$ \\ ${ }^{1}$ Cooperative Research Centre for Aquaculture, CSIRO Livestock Industries, Queensland Bioscience Precinct, \\ 306 Carmody Road, St Lucia, Queensland 4067, Australia
}

${ }^{2}$ Present address: Laboratory of Infectious Diseases, National Institutes of Allergy and Infectious Diseases, Bethesda, Maryland 20892-0720, USA

${ }^{3}$ Present address: Office of the Chief Veterinary Officer, Agriculture Fisheries and Forestry Australia, GPO Box 858, Canberra, ACT 2601, Australia

\begin{abstract}
Chronic and acute gill-associated virus (GAV) infections were examined by in situ hybridization (ISH) using a DNA probe targeting a 779 nucleotide region of the ORF1b-gene. Chronic GAV infections were observed in healthy Penaeus monodon collected from farms and healthy $P$. esculentus surviving experimental infection. During chronic-phase infections in both species, GAV was detected only in partitioned foci of cells with hypertrophied nuclei (spheroids) within the lymphoid organ. Acute-phase infections were observed in moribund P. monodon and P. esculentus infected experimentally with a high dose of GAV, and in moribund $P$. monodon collected from farms during outbreaks of disease. During acute experimental infections in $P$. monodon, ISH detected GAV throughout the lymphoid organ, in gills and in connective tissues throughout the cephalothorax. In moribund P. monodon collected from natural outbreaks of disease, GAV was also detected in the gills and in connective tissues of the cephalothorax, but the distribution of virus within the lymphoid organ varied. In acutely infected $P$. esculentus, GAV was detected in connective tissues, but was restricted to the inner stromal matrix cells and endothelial cells of intact lymphoid organ tubules. The tissue distribution of GAV identified by ISH suggests that shrimp are able to control and maintain chronic asymptomatic infection by a process involving lymphoid organ spheroids. Acute phase infections and the development of disease appear to be dose-related and involve the systemic distribution of virus in connective tissues throughout the cephalothorax.
\end{abstract}

KEY WORDS: Penaeid shrimp $\cdot$ GAV $\cdot$ DNA probe $\cdot$ In situ hybridization

\section{INTRODUCTION}

Gill-associated virus (GAV) is a rod-shaped, enveloped (+) RNA nidovirus that has been associated with sporadic outbreaks of disease and mortalities in farmed Penaeus monodon in Australia (Spann et al. 1997, Cowley et al. 2000b, Walker et al. 2001). Diseased $P$. monodon display lethargy, lack of appetite, red colouration of the cephalothorax and tail, and pinkish colouration of the gills. Similar signs of disease and rapidly progressing mortalities follow experimental injection with infected tissue extracts or by exposure to diseased shrimp tissue by ingestion or immersion (Spann et al. 2000, Spann et al. unpubl.). In diseased shrimp, GAV causes extensive necrosis of the lymphoid organ and there is evidence of a disseminated infection in the gills and other tissues (Spann et al. 1997). However, as has been reported for several 
other shrimp viruses (Bonami et al. 1992, Flegel et al. 1992, Hasson et al. 1995, Tsai et al. 1999), GAV does not always cause disease. Chronic, persistent GAV infection occurs commonly in healthy $P$. monodon farmed in Australia. A survey by reverse transcriptase (RT)-nested PCR of 148 broodstock captured from sites in NE Queensland during 1997 to 1999 has indicated a prevalence of chronic infection approaching 100\% (Walker et al. 2001). A similar prevalence of infection was detected in healthy cultured postlarvae and juvenile $P$. monodon spawned from broodstock collected at these sites. Examination of healthy shrimp by standard histological methods and by transmission electron microscopy has indicated that GAV is restricted primarily to partitioned areas of vacuolated cells with hypertrophied nuclei ('spheroid bodies') within the lymphoid organ (Spann et al. 1995). There is also evidence that GAV is present in the gonads of healthy male and female broodstock and that chronic infection is transmitted vertically during spawning (Walker et al. 2001, Cowley et al. 2002).

In this paper, we apply in situ hybridization (ISH) to compare the tissue distribution of GAV in naturally or experimentally infected Penaeus monodon with acute disease, and in healthy $P$. monodon with natural chronic GAV infections. We also show that experimental infection in Penaeus esculentus, which is not a natural host of GAV, may be chronic or acute, depending on the dose of infection.

\section{MATERIALS AND METHODS}

Source of shrimp and experimental conditions. Three groups of shrimp were collected. Group 1: healthy, sub-adult Penaeus monodon (11 to $17 \mathrm{~g}$ ) were obtained from a farm in SE Queensland in November 1998; Group 2: moribund sub-adult $P$. monodon (14 to $18 \mathrm{~g}$ ) with signs of acute GAV infection were collected from 1 farm in northern Queensland and 1 farm in SE Queensland during disease outbreaks in January and November 1996; Group 3: healthy, sub-adult P. esculentus (10 to $23 \mathrm{~g}$ ) were obtained either from a commercial farm in SE Queensland in March 1997 or from a research facility at CSIRO Marine Research, Cleveland, in November 1997. Some of these shrimp were sacrificed and processed for histology and ISH as described below; the remaining shrimp were maintained in the aquarium facility at CSIRO Long Pocket Laboratories for experimental infections and subsequent histological analyses.

Experimental infections. A filtered GAV inoculum was prepared as described previously from Penaeus monodon collected during an outbreak of disease on a farm in northern Queensland in 1996 (Spann et al.
1997, 2000). Briefly, virus was extracted from the cephalothorax by homogenization in lobster haemolymph medium (LHM; Paterson \& Stewart 1974), clarification, and passage through 0.45 and $0.20 \mu \mathrm{m}$ filters. For experimental infections, $50 \mu \mathrm{l}$ of inoculum was injected into muscle tissue at the second abdominal segment using a 26-gauge needle. Prior to and following infection, shrimp were maintained in $100 \mathrm{l}$ circular plastic tanks in seawater at $26^{\circ} \mathrm{C}$ and 27 ppt salinity. Water was partially exchanged and the shrimp fed pelleted commercial food daily. Uninfected control shrimp were injected with $50 \mu \mathrm{l}$ of LHM and maintained similarly in $100 \mathrm{ltanks}$ in a separate room.

Preparation of fixed tissue sections. Cephalothoraxes were bisected longitudinally, fixed in Davidson's fixative for $48 \mathrm{~h}$, dehydrated through a graded series of ethanol, wax-infiltrated and embedded using standard histological procedures. Sections $(5 \mu \mathrm{m})$ were cut, mounted on silanized slides and either stained with haematoxylin and eosin (H\&E) or used for ISH. Abdomens were not examined in this study.

Preparation of DIG-labeled DNA probe. The origin of the GAV cDNA clone pG12 has been reported previously (Cowley et al. 1999, 2000a). Clone pG12 contains a 779 nucleotide region of the GAV genome overlapping the C-terminus of the conserved helicase domain in the ORF1b gene. To prepare a DIG-labelled pG12 probe, plasmid DNA was prepared using the PERFECTprep ${ }^{\mathrm{TM}}$ plasmid DNA kit (5 Prime-3 Prime), the insert was excised with ECo RI, fractionated by electrophoresis in a $1 \%$ low melting point agarose gel containing $0.5 \mu \mathrm{g} \mathrm{ml}^{-1}$ ethidium bromide and purified using the BRESAclean ${ }^{\mathrm{TM}}$ DNA purification kit (GeneWorks). The DNA probe was prepared from the purified 779 bp insert by random priming and incorporation of DIG (Digoxigenin) using DIG-High Prime (Roche Molecular Biochemicals). The yield of labeled probe was determined by dot-blot of a dilution series of DIG-pG12 DNA onto Hybond N+ membrane (Amersham Pharmacia) followed by detection with anti-DIGalkaline phosphatase Fab fragment (Roche Molecular Biochemicals) according to the manufacturer's instructions.

In situ hybridization (ISH). For ISH, slides prepared as described above were deparaffinized by heating at $65^{\circ} \mathrm{C}$ for $30 \mathrm{~min}$ and immersion in toluene for $16 \mathrm{~min}$, then rehydrated through a graded series of ethanol concentrations. Sections were permeabilized by digestion with $25 \mu \mathrm{g} \mathrm{ml}^{-1}$ Proteinase $\mathrm{K}$ in TNE (50 mM Tris$\mathrm{HCl} \mathrm{pH} 7.4,10 \mathrm{mM} \mathrm{NaCl}, 1 \mathrm{mM}$ EDTA) for $10 \mathrm{~min}$ at $37^{\circ} \mathrm{C}$ and post-fixed with ice-cold $0.4 \%$ formaldehyde for $5 \mathrm{~min}$. Sections were washed briefly in $2 \mathrm{SSC}$ (saline sodium citrate; $1 \mathrm{SSC}=0.15 \mathrm{M} \mathrm{NaCl}, 0.015 \mathrm{M}$ tri-sodium citrate, $\mathrm{pH}$ 7.0) and incubated in hybridization buffer (4 SSC, 50\% formamide, 1 Denhardt's 
reagent, $5 \%$ dextran sulphate, $0.5 \mathrm{mg} \mathrm{ml}^{-1}$ salmon sperm DNA) without probe in a humid chamber at $42^{\circ} \mathrm{C}$ for $1 \mathrm{~h}$. The DIG-labeled DNA probe was denatured by boiling for $10 \mathrm{~min}$. Sections were then incubated in hybridization buffer containing approximately $30 \mathrm{ng}$ denatured DIG-labeled probe in a humid chamber at $42^{\circ} \mathrm{C}$ for at least $15 \mathrm{~h}$.

Following hybridization, sections were washed in SSC of increasing stringency (2 SSC for $20 \mathrm{~min}$ at $25^{\circ} \mathrm{C}, 1 \mathrm{SSC}$ for $20 \mathrm{~min}$ at $42^{\circ} \mathrm{C}, 0.5 \mathrm{SSC}$ for $20 \mathrm{~min}$ at $\left.58^{\circ} \mathrm{C}\right)$ and blocked with Buffer I $(0.1 \mathrm{M}$ Tris- $\mathrm{HCl}$ $\mathrm{pH} 7.5,0.15 \mathrm{M} \mathrm{NaCl}$ ) containing $0.5 \%$ Blocking Reagent (Roche Molecular Biochemicals; Buffer II) at $37^{\circ} \mathrm{C}$ for $30 \mathrm{~min}$. Sections were then incubated in antiDIG-alkaline-phosphatase Fab fragments (Roche Molecular Biochemicals) diluted 1:2000 in Buffer II at $37^{\circ} \mathrm{C}$ for $30 \mathrm{~min}$. Slides were washed in Buffer III $(100 \mathrm{mM}$ Tris- $\mathrm{HCl} \mathrm{pH}$ 9.5, $100 \mathrm{mM} \mathrm{NaCl}, 50 \mathrm{mM} \mathrm{MgCl}_{2}$ ) for $20 \mathrm{~min}$ at room temperature and incubated in colour developer (38 $\mathrm{\mu l}$ nitro-blue tetrazolium [100 mg $\mathrm{ml}^{-1}$ ] and $38 \mu \mathrm{l}$ 5-bromo-4-chloro-3-indoyl phosphate [150 mg ml${ }^{-1}$ ] in $10 \mathrm{ml}$ Buffer III) in a dark, humid chamber for 15 to $60 \mathrm{~min}$. Colour development was stopped by immersion in 1 TN $(1 \mathrm{mM}$ Tris- $\mathrm{HCl}$ $\mathrm{pH}$ 8.0, $0.1 \mathrm{mM} \mathrm{NaCl}$ ) for $20 \mathrm{~min}$. Slides were then counter-stained in $0.5 \%$ Bismarck brown for $2.5 \mathrm{~min}$, dehydrated through a graded series of ethanol, cleared with toluene and mounted under cover slips.

\section{RESULTS}

\section{Chronic GAV infection in healthy sub-adult Penaeus monodon}

Healthy sub-adult Penaeus monodon collected from a farm in SE Queensland and infected naturally with
GAV were sacrificed, fixed and examined by histology and ISH. By histology, the lymphoid organs appeared normal except for the presence of distinct partitioned areas of vacuolated cells containing hypertrophied nuclei (i.e. spheroid bodies). By ISH, GAV was detected only in the cytoplasm of cells within in the spheroid bodies (Fig. 1a). There was no evidence of infection other than in lymphoid organ cells. Other tissue types including connective, cardiac, muscular and intestinal tissues were histologically normal and displayed no evidence of GAV infection by ISH.

\section{Acute GAV infection in experimentally infected Penaeus monodon}

Healthy Penaeus monodon collected from a farm in SE Queensland were infected experimentally by injection with an undiluted standard inoculum prepared from an extract of shrimp from an outbreak of acute GAV disease. Progressively accumulating mortalities were observed from $5 \mathrm{~d}$ post-injection. Moribund shrimp displayed gross signs of disease characteristic of acute GAV infection (Spann et al. 1997). Histological examination of lymphoid organs revealed extensive cellular necrosis, loss of defined tubule structure and tubule lumen occlusion. However, the degree to which this occurred varied between individuals and, in most cases, some tubules remained intact. Spheroid bodies were either absent or comprised less than $10 \%$ of the lymphoid organ section. By ISH, GAV was detected throughout the lymphoid organ, both in areas where tubule structure had been lost (Fig. 1b) and within intact tubules (Fig. 1c). When spheroids were present, cells within these structures reacted with the ISH probe (Fig. 1b). Within intact tubules, GAV was either detected
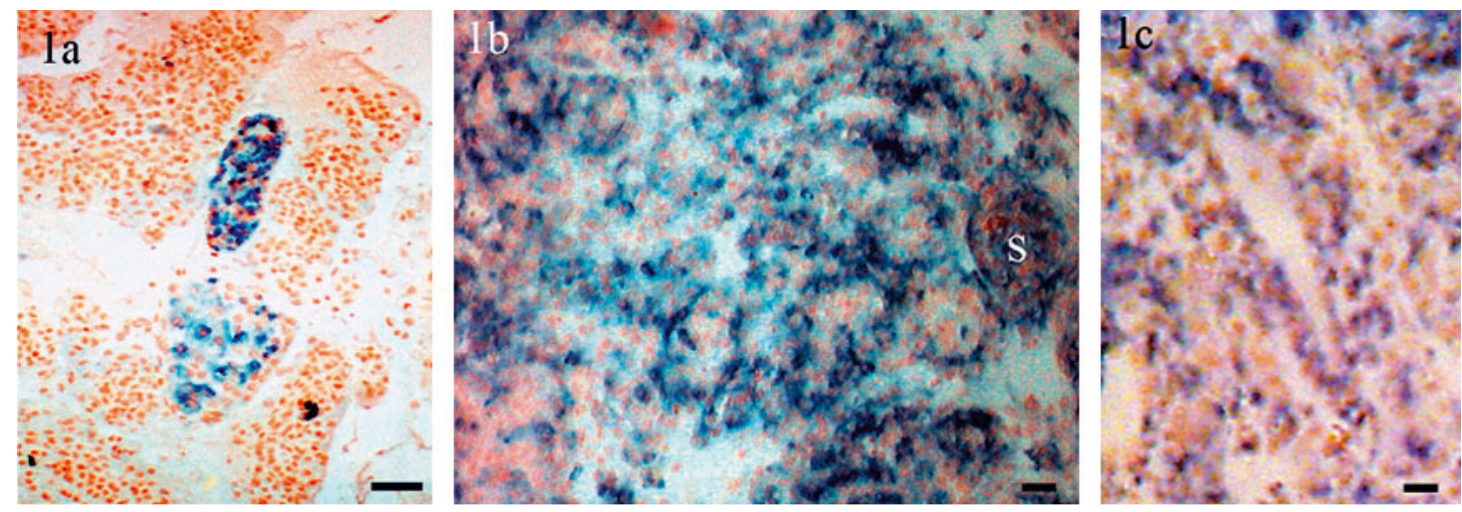

Fig. 1. Penaeus monodon. In situ hybridization using a DIG-labeled gill-associated virus (GAV) probe with the lymphoid organ of GAV-infected P. monodon. Tissues are counter stained with Bismarck brown. (a) Natural, chronic GAV infection showing spheroids, scale bar $=50 \mu \mathrm{m} ;(\mathrm{b}, \mathrm{c})$ experimental GAV infection in which the virus is distributed throughout areas of tubule necrosis (b) and within intact tubules (c), scale bars $=20 \mu \mathrm{m}$. S: spheroid body 
throughout the stromal matrix (Fig. 1c) or restricted to cells at the periphery of the tubule and adjacent to the central lumen.

Although there was no evidence of cellular necrosis, ISH also detected GAV in the connective tissues of most major organs. In the hepatopancreas, the probe reacted with the interstitial connective tissues between the tubules (Fig. 2a) and the organ capsule connective tissues. Hepatopancreocytes were ISH probe-negative. In the midgut caecae, epithelial cells were negative but spongy connective tissues were positive (Fig. 2b). Epithelial cells of the stomach gave a strong positive reaction, as did connective tissue directly adjacent to the epithelial layer (Fig. 2c). In only 1 individual was a positive signal detected in a few cells of the dorsal subcuticular epidermis. In the supraesophageal ganglion,
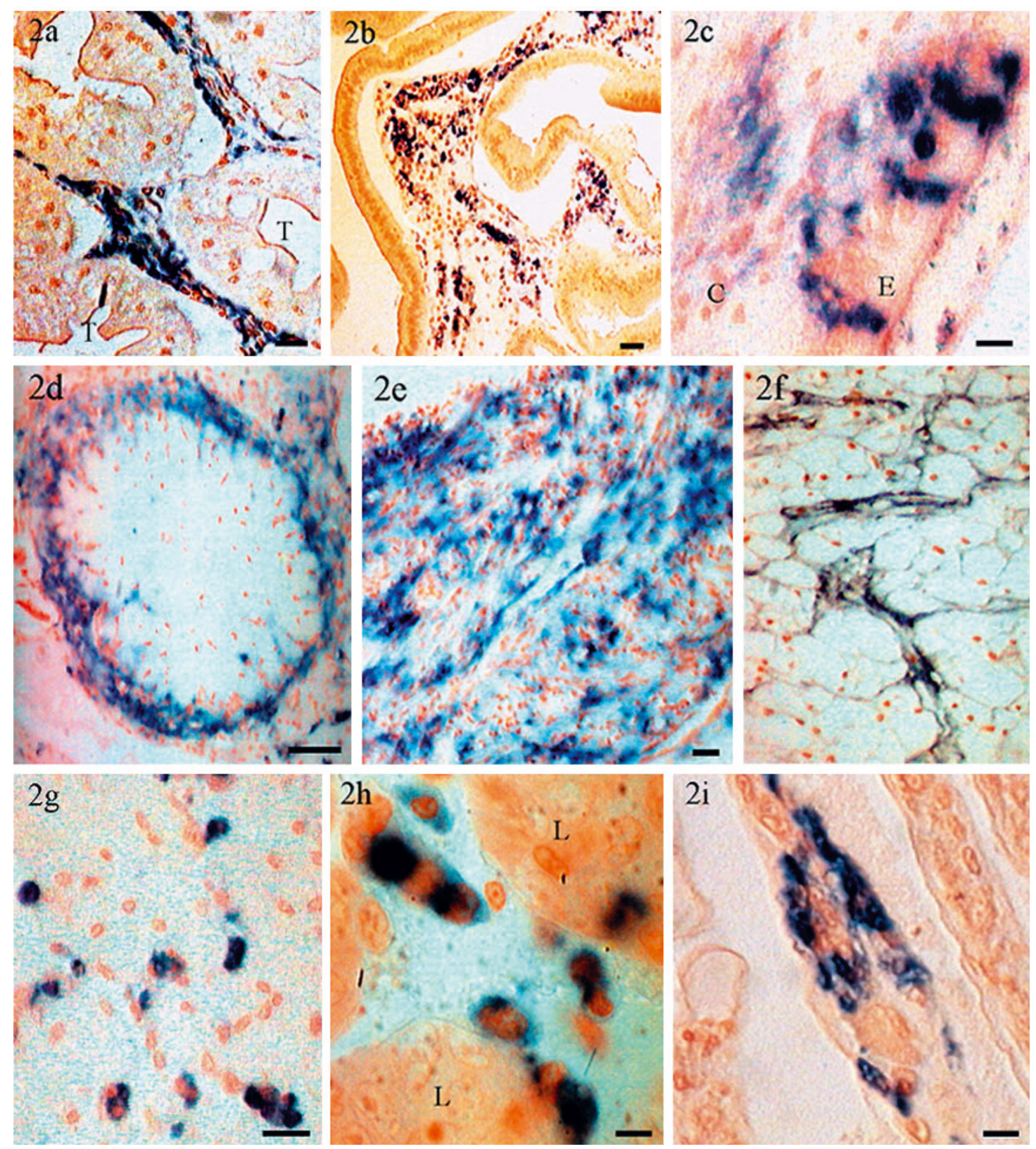

Fig. 2. Penaeus monodon. In situ hybridization using a DIG-labeled gill-associated virus (GAV) probe with various tissues of moribund P. monodon infected experimentally with GAV. (a) Hepatopancreas, scale bar $=20 \mu$; $($ b) midgut caecae, scale bar $=$ $50 \mu \mathrm{m}_{i}$ (c) cuticular epithelium of the stomach, scale bar $=10 \mu \mathrm{m}_{i}$ (d) anterior antennule neuropile, scale bar $=50 \mu \mathrm{m}_{i}(\mathrm{e})$ circum-

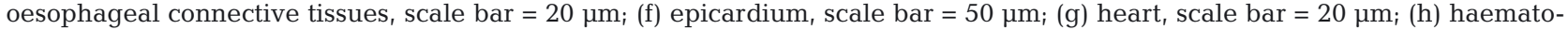
poietic tissues, scale bar $=10 \mu \mathrm{m}$; (i) gills, scale bar $=10 \mu \mathrm{m}$. T: tubule; C: cuticle; E: epithelium; L: lymphoid organ 
the probe reacted with glial cells around the anterior antennule neuropile (Fig. 2d), within the cortical glia, and glial cells of the circumoesophageal connectives (Fig. 2e). Glial cells of the ventral nerve cord were also positive. The neuro-secretory, globuli and giant cells of the supraesophageal ganglion and segmental ganglia were negative. In the heart, the connective tissues of the epicardium gave a positive signal (Fig. 2f). Myocardial cells were negative but, in some individuals, the fixed phagocytes were positive (Fig. 2g). The connective tissues of the antennal gland and the muscle bundles in the head region gave a positive reaction (not shown). In haematopoietic tissues, the parenchymal cells of the lobules were negative but the developing haemocytes between the lobules were positive (Fig. 2h). A positive signal was observed in the central axes and the epithelial pillar cells of the primary and secondary filaments of the gills (Fig 2i) and was, in some cases, associated with necrosis and fusion of the filament tips.

\section{Acute GAV infection in Penaeus monodon collected from disease outbreaks on farms}

Fixed, stored tissues from moribund sub-adult Penaeus monodon (14 to $18 \mathrm{~g}$ ) collected from 2 farms during disease outbreaks in Queensland during 1996 were also examined by histology and ISH. The histopathological features of the lymphoid organs in these diseased shrimp were similar to those observed in acute experimental infections. Approximately $50 \%$ of diseased shrimp contained no detectable spheroid bodies. In 1 individual, the spheroids were amorphous and distinct boundaries between spheroids and tubules were not clear. Loss of defined tubule structure was observed in some lymphoid organs, although less frequently than observed in moribund $P$. monodon from experimental infections and, in all lymphoid organs, most tubules retained their structure. Approximately $50 \%$ of lymphoid organs also displayed 'gapping' (abnormal interstitial spaces) between the tubules (Fig. 3c). This was not observed in moribund $P$. monodon infected experimentally with GAV. By ISH, the distribution of GAV within the tubules of diseased farm shrimp varied from being diffuse to favoring the cells lining the central lumen and around the periphery of intact tubules (Fig. 3b). In 1 individual, a positive probe signal was predominantly observed in areas of necrotic and vacuolated cells between intact tubules (Fig. 3a).

The distribution of GAV in connective tissues varied among different individuals collected from disease outbreaks on farms. However, the interstitial and capsule connective tissues of the hepatopancreas and the connective tissues of the midgut caecae were ISH probe-positive in all cases. The probe also consistently reacted with the epithelial cells of the gills.

\section{Acute GAV infection in experimentally infected Penaeus esculentus}

As the prevalence of GAV infection approaches $100 \%$ in wild and farmed Penaeus monodon in eastern Australia (Walker et al. 2001), experimental GAV infection in this species must assume a pre-existing chronic state of infection. Therefore, experimental infections were also conducted in $P$. esculentus which is not a natural carrier of chronic GAV infection but is susceptible to disease following injection with GAV (Spann et al. 2000).

Healthy sub-adult Penaeus esculentus were injected with the undiluted standard GAV inoculum. Progressively accumulating mortalities were observed from $3 \mathrm{~d}$ post-inoculation. Moribund shrimp displayed gross signs of disease characteristic of acute GAV infection in $P$. monodon, including red body colouration, pink gill colouration and lethargy. Histological examination of moribund $P$. esculentus revealed no loss of lymphoid organ tubule structure, as had been observed in $P$. monodon. However, almost all tubules displayed occluded lumens (Fig. 3d). By ISH, GAV infection was detected only in the endothelial cells and inner matrix cells lining the lumen (Fig. 3e). Haemocytes within the lumen of the tubules were probe-negative. The cells lining the sub-gastric artery were probe-positive (Fig. 3f). A positive ISH signal was observed in the connective tissues of the hepatopancreas and midgut caecae, and in the spongy connective tissues under the dorsal cuticle. The epithelial cells of the gills and underlying connective tissues of the stomach were also probe-positive. $P$. esculentus that had been mockinfected with lobster haemolymph medium did not react with the probe (not shown).

\section{Chronic GAV infection in experimentally infected Penaeus esculentus}

The tissue distribution of GAV was also examined in Penaeus esculentus that were infected experimentally with a sub-lethal dose of virus. Healthy sub-adult $P$. esculentus were injected with either an undiluted or diluted ( $10^{-6}$ ) preparation of the standard GAV inoculum. Three of 20 shrimp remained alive $45 \mathrm{~d}$ after being injected with the undiluted inoculum, and cephalothorax tissues from these surviving shrimp were fixed and examined by histology and ISH. The $P$. esculentus contained lymphoid organ spheroids 


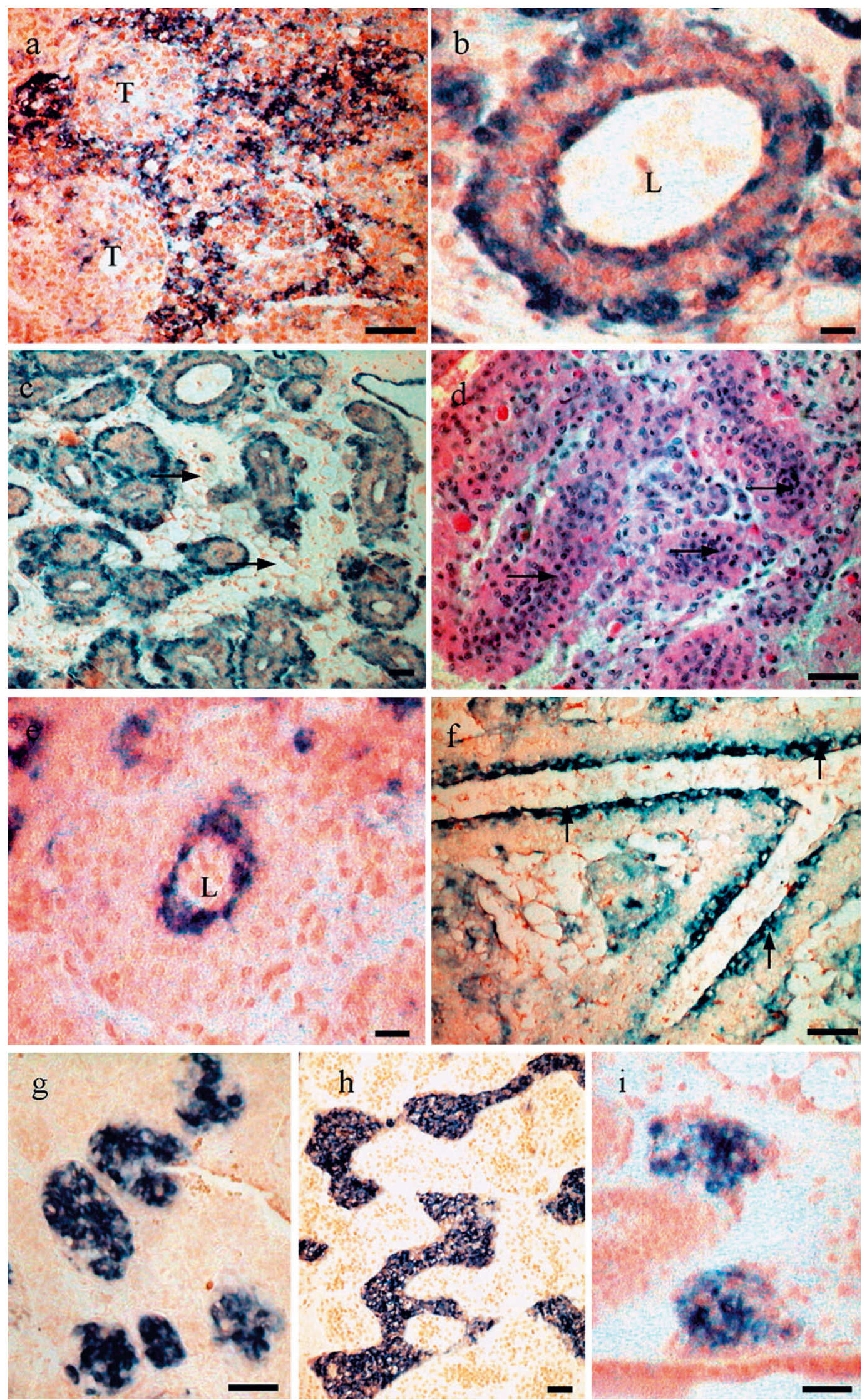


Fig. 3. Penaeus monodon and P. esculentus. In situ hybridization using a DIG-labeled gill-associated virus (GAV) probe with various tissues of GAV-infected P. monodon and P. esculentus. (a-c) Moribund P. monodon infected naturally with GAV; (a) infection in areas of necrotic, vacuolated cells between lymphoid organ tubules (T), scale bar $=20 \mu m_{\text {; }}(\mathrm{b})$ infection in cells surrounding the lumen (L) of a lymphoid organ tubule, scale bar $=50 \mu \mathrm{m}$; (c) gapping (arrow) in tissues between tubules, scale bar $=50 \mu \mathrm{m}$. (d-f) Moribund P. esculentus infected experimentally with a high dose of GAV; (d) lymphoid organ tubules with occluded lumens (arrows), scale bar $=50 \mu m_{i}$ (e) infected cells lining the lumen (L) of lymphoid organ tubules, scale bar $=20 \mu m_{i}$ (f) infection in cells lining the sub-gastric artery (arrows), scale bar $=50 \mu \mathrm{m}_{i}(\mathrm{~g}) P$. esculentus surviving infection with a high dose of GAV. Infection confined to lymphoid organ spheroids, scale bar $=50 \mu \mathrm{m}$. (h-i) P. esculentus infected with a sublethal dose of GAV; (h) zones of infected lymphoid organ cells, scale bar $=50 \mu \mathrm{m}$; (i) ectopic spheroids in the hepatopancreas, scale bar $=50 \mu \mathrm{m}$

typical of natural, chronic GAV infection in Penaeus monodon. By ISH, the spheroids reacted with the GAV probe but the surrounding healthy tubules were probe-negative (Fig. 3g). GAV infection was not detected in any other tissue examined by ISH. $P$. esculentus administered a $1 \quad 10^{-6}$ diluted dose of the standard inoculum also displayed histopathology characteristic of chronic GAV infection from $14 \mathrm{~d}$ post-injection. The lymphoid organs of all shrimp examined contained probe-positive spheroids or zones of necrotic and vacuolated cells between normal tubules (Fig. 3h). The histology of all other organs appeared normal and GAV was not detected by ISH. However, in 1 individual, probe-positive ectopic spheroids were identified in the connective tissues of the hepatopancreas adjacent to the lymphoid organ (Fig. 3i). P. esculentus mock-infected with lobster haemolymph medium displayed normal histology and no ISH reactions occurred with the GAV probe.

\section{DISCUSSION}

This paper describes the use of ISH to characterize the chronic and acute phases of GAV infection in naturally and experimentally infected shrimp. The study has examined healthy Penaeus monodon carrying a natural, persistent GAV infection, moribund $P$. monodon collected from ponds during disease outbreaks, and $P$. monodon super-infected experimentally with a high dose of GAV. The study has also examined dose-related states of infection in $P$. esculentus which, although not natural carriers of GAV, are susceptible to experimental infection and disease (Spann et al. 2000). Aspects of the histopathology of GAV infections in P. monodon have been reported previously (Spann et al. 1995, 1997). The specificity of ISH has allowed a more definitive investigation of the distribution of virus during the chronic and acute infection states and has shown that chronic infections can be established without the onset of disease by exposure to a low dose of virus.

In healthy, juvenile Penaeus monodon infected naturally with GAV, ISH detected virus only in the cytoplasm of hypertrophied cells within lymphoid organ spheroids (Fig. 1a). This supports previous observations by TEM and histology on the distribution of GAV (previously also named lymphoid organ virus, LOV) during chronic states of infection (Spann et al. 1995). We have also reported previously that low levels of GAV can be detected in the gills and haemocytes of healthy juveniles by RT-PCR (Cowley et al. 2000a), and higher levels of virus have been observed in the gonads of healthy $P$. monodon broodstock (Walker et al. 2001, Cowley et al. 2002). Failure to detect GAV by ISH in tissues other than the lymphoid organ is likely to reflect the abundance of virus in spheroids and the relative insensitivity of these probes compared to RTnested PCR. The application of in situ RT-PCR (Brodie et al. 1998) may reveal whether PCR targets detected in other tissues are indicative of low levels of active viral replication.

During the acute phase of infection in moribund, experimentally infected Penaeus monodon, GAV was detected by ISH throughout the lymphoid organ in which tubule structure was no longer differentiated due to extensive tissue necrosis (Fig 1b). GAV was also commonly detected in many connective tissues, as well as haemocytes, glial cells and epithelial cells of the stomach and gill filaments (Fig. 2). Tang et al. (2002) have recently reported a similar distribution of GAV in P. monodon and Litopenaeus vannamei during acute experimental infection using a cross-reacting YHV (yellow head virus) DNA probe.

In moribund Penaeus monodon infected naturally with GAV, the extent of loss of tubule structure varied between individuals (Fig, 3a-c). However, naturally infected shrimp in acute phase generally displayed less necrosis of the lymphoid organ and more variable probe signal within the lymphoid organ and other tissues than shrimp infected experimentally. Shrimp injected with undiluted inocula clearly receive a large dose of virus and the associated lymphoid organ histopathology may well reflect an extreme situation that rarely occurs in nature. We have estimated by titration in vivo that undiluted GAV inocula contain up to $10^{8}$ infectious doses and can cause mortalities in juvenile $P$. monodon when diluted to $10^{-5}$ (I.J.E. \& P.J.W. unpubl. data). As almost all farmed P. monodon 
in Australia carry a pre-existing chronic GAV infection, acute-phase infections and associated mortalities may occur when environmental stress factors such as temperature or low dissolved oxygen levels aggravate the chronic condition (Flegel et al. 1997, Tsai et al. 1999, Vidal et al. 2001). There is also evidence that both chronic and acute GAV infections may be transmitted horizontally by ingestion or immersion (Spann et al. unpubl.). The variability in histopathology of the lymphoid organ in moribund farmed shrimp with acute GAV infections may reflect variations in the initial route and dose of infection and the likelihood that acute infections in ponds derive from pre-existing chronic infections.

Penaeus esculentus injected with a high dose of GAV also developed an acute infection and displayed a similar distribution of virus as P. monodon, but there was no loss of tubule structure in the lymphoid organ and the virus did not appear as widespread within the lymphoid organ or connective tissues (Fig. 3d-f). GAV was detected in cells lining the sub-gastric artery and tubule lumen within the lymphoid organ. As haemolymph first enters the lymphoid organ via the subgastric artery and must pass through the thin layer of endothelial cells lining the lumen before entering the stromal matrix of the tubules (Oka 1969, Martin et al. 1987, Anggraeni \& Owens 2000), this may be indicative of an early stage of infection in the lymphoid organ. Tang et al. (2002) also reported no loss of normal tubule structure in GAV-infected Litopenaeus vannamei which, like $P$. esculentus, is not a natural host of GAV.

We have reported previously that acute GAV infection and associated mortalities develop more slowly in Penaeus esculentus than in P. monodon and some individuals survive an acute GAV infection, even when the dose of virus is relatively high (Spann et al. 2000). In survivors of high dose infection and in $P$. esculentus infected with a very low dose of GAV, lymphoid organ spheroids containing probe-positive cells typical of chronic infection in P. monodon were formed and GAV was not detected by ISH in any other tissue (Fig. 3g-h). In some $P$. esculentus infected with a low dose of GAV, 'zones' of infected cells were observed between normal tubules. Similar areas of infection between intact tubules were also observed in the lymphoid organs of $P$. monodon with natural, acute infection. However, in healthy $P$. esculentus the infected zones were clearly differentiated from normal tubules and not as widespread. These zones may be distended haemal sinuses in which phagocytes and other haemocytes containing sequestered GAV have accumulated (Anggraeni \& Owens 2000). The 'gapping' observed in some shrimp (Fig. 3i) suggests that the haemal sinuses and connective tissues become necrotic as a result of the heavy accumulation of infected cells and contribute to the development of disease.

Lymphoid organ spheroids have been observed during infection with several other shrimp viruses, and it has been proposed that spheroid formation is indicative of a non-specific defensive response (Owens et al. 1991, Bonami et al. 1992, Flegel et al. 1992, Hasson et al. 1995). Hasson et al. (1999a) and Anggraeni \& Owens (2000) have suggested that spheroids are formed when resident phagocytes, or haemocytes migrating from the tubule lumen through the stromal matrix, sequester virus and accumulate in the haemal sinuses between the tubules. Based on cytopathology and ISH probe reactions during recovery from TSV infections, Hasson et al. (1999a) classified spheroids in Litopenaeus vannamei as 3 distinct and serial morphotypes. The Type A morphotype, the earliest detected, appeared to originate from lymphoid organ phagocytes that had sequestered TSV, and was characterised by a lightly basophilic, homogeneous cell mass containing few necrotic cells. Type B spheroids, which appeared to evolve from Type A, contained increased numbers of necrotic cells with pyknotic nuclei and moderate vacuolization and remained persistently infected with TSV. Type C spheroids, in which there was no evidence of TSV infection by ISH, developed later and contained condensed, highly basophilic nuclei and increased cytoplsamic vacuolization characteristic of apoptosis (Hasson et al. 1999b). The spheroids we have observed in healthy Penaeus monodon with natural, chronic GAV infections, and in $P$. esculentus surviving experimental infection, resemble Type B spheroids, displaying a diffuse probe signal, vacuolization, pyknotic nuclei and some cell necrosis. Type B spheroids were also reported to be the most common morphotype during the chronic phase of TSV infection (6 to $16 \mathrm{wk}$ post-infection) (Hasson et al. 1999b). The focal concentration of GAV in Type B spheroids during natural chronic infection in P. monodon and in survivors of experimental infection in $P$. esculentus suggests active sequestration of virus does occur and this may modulate the spread and replication of virus in other tissues. The capacity of shrimp to contain GAV infection appears to be dose-related. As chronic GAV infections are also transmitted vertically during spawning (Cowley et al. 2002), the route of infection and age of the shrimp may also influence their capacity to contain the infection and avoid disease.

For TSV, Hasson et al. (1999b) have proposed a model in which spheroids have a central role in the modulation of infection. According to this model, TSV may continue to replicate within Type B spheroids, escape and enter the circulatory system, and return to the lymphoid organ where it is sequestered by phagocytes and new spheroids are formed. Alternatively, 
spheroids eventually eliminate the virus through apoptosis of infected cells, clearing the infection and resulting in a normal lymphoid organ. Hasson et al. (1999b) suggest that these processes probably occur concurrently in chronic infection. Depending on the balance of the outcomes, infection may remain persistent or be cleared from the shrimp. However, our observations suggest that the former process dominates in chronic GAV infection. The very high prevalence of chronic GAV infection in Penaeus monodon postlarvae, juveniles and broodstock in eastern Australia (Walker et al. 2001) indicates that the virus is rarely cleared from infected shrimp, and the presence of GAV in haemolymph suggests a cyclic systemic infection (Cowley et al. 2000a). We have also observed that following experimental infection at low dose, $P$. esculentus lymphoid organs remain PCR-positive for at least $50 \mathrm{~d}$ (I.J.E. \& P.J.W. unpubl. data). Indeed, life-long, persistent, chronic infections and vertical transmission appear to be key elements of the GAV infection cycle, sustaining the virus in shrimp populations in the absence of disease (Walker et al. 2001, Cowley et al. 2002).

Despite the high prevalence of chronic GAV infection in wild and farmed Penaeus monodon, disease outbreaks are not common in Australia and little is yet known of the process by which ubiquitous chronic, persistent infections result in disease and mortalities. Understanding the transition from chronic to acute infection may identify environmental stress as a factor that can compromise the capacity of the host to maintain the chronic infection state and allow the identification of functional indicators of impending disease. At present, the detection of virus outside lymphoid organ spheroids is the most useful indicator of a transition to disease. ISH provides a reliable means of detecting GAV in lymphoid organ tubules, gill and connective tissues that appear normal using standard histological stains and may prove to be a useful tool with which to identify early, asymptomatic stages of disease development.

Acknowledgements. We would like to thank Gold Coast Marine Aquaculture and CSIRO Marine Research, Cleveland, for supplying experimental shrimp and Mr. Sam Johnson, CSIRO Livestock Industries, for assistance with digital imaging.

\section{LITERATURE CITED}

Anggraeni MS, Owens L (2000) The haemocytic origin of lymphoid organ spheroid cells in the penaeid prawn Penaeus monodon. Dis Aquat Org 40:85-92

Bonami JR, Lightner DV, Redman RM, Poulos BT (1992) Partial characterisation of a togavirus (LOVV) associated with histopathological changes of the lymphoid organ of penaeid shrimps. Dis Aquat Org 14:145-152

Brodie SJ, Bardsley KD, Diem K, Mecham JO, Norelius SE, Wilson WC (1998) Epizootic haemorrhagic disease: analysis of tissues by amplification and in situ hybridisation reveals widespread orbivirus infection in low copy numbers. J Virol 72:3863-3871

Cowley JA, Dimmock CM, Wongteerasupaya C, Boonsaeng V, Panyam S, Walker PJ (1999) Yellow head virus from Thailand and gill-associated virus from Australia are closely related but distinct viruses. Dis Aquat Org 36:153-157

Cowley JA, Dimmock CM, Spann KM, Walker PJ (2000a) Detection of Australian gill-associated virus (GAV) and lymphoid organ virus (LOV) of Penaeus monodon by RTnested PCR. Dis Aquat Org 39:159-167

Cowley JA, Dimmock CM, Spann KM, Walker PJ (2000b) Gill-associated virus of Penaeus monodon prawns: an invertebrate virus with ORF1a and ORF1b genes related to arteri- and coronaviruses. J Gen Virol 81:1473-1484

Cowley JA, Hall MR, Cadogan LC, Spann KM, Walker PJ (2002) Vertical transmission of gill-associated virus (GAV) in the black tiger prawn Penaeus monodon. Dis Aquat Org 50:95-104

Flegel TW, Fegan DF, Kongsom S, Vuthikornudomkit S and 5 others (1992) Occurrence, diagnosis and treatment of shrimp diseases in Thailand. In: Fulks W, Main KL (eds) Diseases of cultured penaeid shrimp in Asia and the United States. The Oceanic Institute, Honolulu, p 57-112

Flegel TW, Boonyaratpalin S, Withychumnarnkul B (1997) Progress in research on yellow-head virus and white spot virus in Thailand. In: Flegel TW, McCrae IH (eds) Diseases in Asian aquaculture III. Fish Health Section, Asian Fisheries Society, Manila, p 285-295

Hasson KW, Lightner DV, Poulos BT, Redman RM, White BL, Brock JA, Bonami JR (1995) Taura syndrome in Penaeus vannamei: demonstration of a viral etiology. Dis Aquat Org 23:115-126

Hasson KW, Lightner DV, Mohney LL, Redman RM, Poulos BT, White BM (1999a) Taura syndrome virus (TSV) lesion development and the disease cycle in Pacific white shrimp Penaeus vannamei. Dis Aquat Org 36:81-93

Hasson KW, Lightner DV, Mohney LL, Redman RM, White BM (1999b) Role of lymphoid organ spheroids in chronic Taura syndrome virus (TSV) infections in Penaeus vannamei. Dis Aquat Org 38:93-105

Martin GG, Hose LE, Kim JJ (1987) Structure of hematopoietic nodules in the ridgeback prawn, Sicyonia ingentis: light and electron microscopic observations. J Morphol 192:193-204

Oka M (1969) Studies on Penaeus orientalis Kishinouye. VIII. Structure of the newly found lymphoid organ. Bull Jpn Soc Sci Fish 35:245-250

Owens L, De Beer S, Smith J (1991) Lymphoid parvo-like particles in Australian penaeid prawns. Dis Aquat Org 11:129-134

Paterson WD, Stewart JE (1974) In vitro phagocytosis by hemocytes of American lobster (Homarus americanus). J Fish Res Board Can 31:1051-1056

Spann KM, Vickers JE, Lester RJG (1995) Lymphoid organ virus of Penaeus monodon from Australia. Dis Aquat Org 23:127-134

Spann KM, Cowley JA, Walker PJ, Lester RJG (1997) A yellow-head-like virus from Penaeus monodon cultured in Australia. Dis Aquat Org 31:169-179

Spann KM, East IJ, Donaldson RA, Cowley JA, Walker PJ (2000) Differences in the susceptibility of some penaeid prawn species to gill-associated virus (GAV) infection. Dis Aquat Org 42:221-225 
Tang KFJ, Spann KM, Owens L, Lightner DV (2002) In situ detection of Australian gill-associated virus with a yellow head virus gene probe. Aquaculture 205:1-5

Tsai MF, Kou GH, Liu HC, Liu KF and 5 others (1999) Longterm persistence of white spot syndrome virus (WSSV) in a cultivated shrimp population without disease outbreaks. Dis Aquat Org 38:107-114

Vidal OM, Granja CB, Aranguren F, Brock JA, Salazar M (2001) A profound effect of hyperthermia on survival of

Editorial responsibility: Timothy Flegel,

Bangkok, Thailand
Litopenaeus vannamei juveniles infected with white spot syndrome virus. J World Aquacult Soc 32:364-372

Walker PJ, Cowley JA, Spann KM, Hodgson RAJ, Hall MA, Withyachumnarnkul B (2001) Yellow head complex viruses: transmission cycles and topographical distribution in the asia-pacific region. In: Browdy CL, Jory DE (eds) The new wave. Proc Spec Session Sustainable Shrimp Culture, Aquaculture 2001. The World Aquaculture Society, Baton Rouge, FL, p 227-237

Submitted: July 23, 2002; Accepted: April 1, 2003

Proofs received from author(s): August 7, 2003 